\title{
Kampanya Öncesi Reklam Araştırmalarının Reklam Kampanyasının Uygulanmasındaki Rolü ve Önemi
}

\author{
Eda $\mathrm{Er}^{*}$ \\ Ege Üniversitesi, İletişim Fakültesi, İzmir
}

\begin{abstract}
$\ddot{O} z$
İş dünyası ile ilgili akademik ve popüler makalelerin işaret ettiği gibi, günümüzün piyasa koşulları ve buna bağh olarak pazar yapısı oldukça gelişmiş ve karmaşıklaşmış bir inceleme alanı durumuna gelmiştir. Böylesi bir ortam içinde, işletmelerin hedef kitleleri ile etkili bir iletişim kurmaları ve ürün satışların arttırabilmeleri için reklam önemli bir araç olarak ön plana çıkmakta ve işlev görmektedir. Pahalı bir yatırım aracı olarak reklam; pazar ve tüketici, reklamın amaçları ve mesajl, kampanya ve medya stratejisi, bütçeleme ve reklamın etkisi hakkında veriler sağlayan kampanya öncesi spesifik araştırmaların yapılmasını gerektirmektedir. Bu nedenle reklama ilişkin araştırmalar, reklam stratejilerinin uygulanması sırasında planlama ve karar alma süreçlerinde belirleyici bir role sahiptir. Bu noktada, pre-testler reklamın olası başarısını ölçme hususunda ayrıca önem taşımaktadır. Reklamın uygulanmasındaki hayati öneminden dolayı, çalışmamız kampanya öncesi reklam araştırmalarına, bu araştırmaların reklam kampanyalarının uygulanması sürecindeki önemini, kullanım alanını ve rolünü ele alacak şekilde odaklanmaktadır.
\end{abstract}

Anahtar Kelimeler: Reklamcılık, Reklam Kampanyası, Kampanya Öncesi Reklam Araştırması, Pre-test.

\section{The Importance and the Role of Pre-campaign Reserach in the Advertisement Campaigns}

\begin{abstract}
As popular and academic articles indicate, marketing structure and market conditions has become highly developed and complex field of study today. In this environment, advertising has gained far more importance for companies to communicate effectively with their target audiences, and to increase their sales. As an expensive investment, advertising requires specific pre-campaign researches which will provide data on market and consumer, advertising objectives and message, campaign and media strategy, budgeting, and the effect of an advertisement. Therefore, researches on advertising have a decisive role during the planning and decision-making processes in the execution of advertising strategies. At this point, pre-testing is also important for evaluating the likely success of an advertisement. Because of its vital importance for the practice of advertising, our study will focus on pre-campaign advertising researches reviewing their importance, use and role in the execution of advertising campaigns.
\end{abstract}

Key Words: Advertising, Advertising Campaign, Pre-campaign Advertising Researches, Pre-test.

\section{GíRIŞ}

İş ve iletişim ortamının mevcut şartları içinde, satışlarında başarılı olmak isteyen bir işletmenin en fazla önem vermesi gereken alanlardan birisi pazarlama ve pazarlama faaliyetleri içinde gerçekleştirilen reklamlardır. Günümüzün daha önce olmadığı kadar gelişmiş ve karmaşıklaşmış pazar yapısı içinde, en küçük işletmeden 
küresel işletmelere kadar tüm şirketlerin reklam mesajına doymuş bir ortamda dikkat çekmek için araştırma sonuçlarına dayalı reklamcılık faaliyetlerine ihtiyaçları bulunmaktadır. Özellikle büyük işletmelerde reklama ilişkin kararlar daha karmaşık süreçleri içerdiği ve daha fazla personelin eşgüdümlü çabalarını gerektirdiği için, reklam kampanyalarında araştırma süreci içinde daha fazla sayıda uzmanın desteğine ihtiyaç bulunmaktadır. Fazla sayıda yönetici ve yaratıcı personelin eşgüdümlü çalışmasını gerektiren bu süreç içinde, araştırma sonuçlarının verilerine duyulan ihtiyaç nedeniyle reklam kampanyasının başarısı açısından araştırma sonuçlarına dayanılması yaşamsal bir değer taşımaktadır. Çünkü reklam faaliyetleri büyük bir finansal yatırım anlamına gelmektedir; her reklam veren doğal olarak bu yatırımının karşılığını almak istemektedir. Reklam araştırmalarının reklamcılık uygulamaları açısından taşıdığı bu işlevi nedeniyle, çalışmamızda reklam kampanyalarının planlanması öncesinde reklam araştırmalarının önemi, yararı, uygulamadaki katkısı ve rolü üzerine bir inceleme gerçekleştirilecektir.

\section{Reklam Kampanyalarının Tanımlanması}

Reklam kampanyası öncesi reklam araştırmalarının önemini incelemeye başlamadan önce, ilk olarak bir tanımlama yapmakta yarar bulunmaktadır. "Bir reklam kampanyası, spesifik bir hedef kitleye yönelik olarak hazırlanmış, belirli bir eylemde bulunmasını sağlamak üzere bu izlerkitleye yönelik bilgilendirme ve/ya da ikna etme ve/ya da hatırlatma amacını taşıyan bir mesajın farklı iletişim ortamlarında maksatlı, etkili ve kişisel dağıtımıdır" (Theron, 2007: 144). Tanımın ortaya koyduğu gibi, bir reklam kampanyası farklı medyalarda yer almakta ve reklam mesajının temel temasını ya da düşüncesini hedef kitlenin ve medyanın özelliklerine göre tasarlanmış şekilde aktarmakta; bu aktarımı belirli bir zaman süreci içinde gerçekleştirmekte ve reklam verenin uzun vadeli amaçlarına uygunluk taşımaktadır.

Temel reklam stratejisine bağlılık oluşturulması ve uzun vadedeki tutarlılığ bakımından, reklam kampanyalarının, araştırma sonuçlarına ve verilerine dayanması zorunluluğu bulunmaktadır. "Firma yöneticileri reklam kararlarını verirken genellikle uzun dönemde etkili olacak reklam seçimini sağlamak isterler. Bu nedenle şu soruların cevaplarını karar aşamasında vermek durumundadırlar: Kârı yükseltmek için reklamın başarıyla kullanacağı firsatlar nerelerdedir? Reklam hangi alanlarda öteki satış tutundurma tekniklerinden daha etkin sonuçlar sağlar? Reklam nasıl iyileştirilip geliştirilebilir? Reklamın maliyet giderleri, sonuçlarına oranla nasıl daha azaltılabilir? Reklamın sonuçları daha doğru bir biçimde nasıl ölçülebilir veya tahmin edilebilir?" (Oluç'tan aktaran: Babacan, 2005: 49). Reklam araştırması aracılığıyla yukarıdaki sorulara karşılık olarak elde edilecek bulgular, reklam kampanyasının temel stratejisinin belirlenmesinde anahtar rol oynamaktadır. Bir işletmenin reklam kampanyasına başlamadan önce bilgi toplanılması ve analiz edilmesi gereken süreçler ise şu şekilde saptanmaktadır (Kocabaş ve Elden, 2006: 53):

- "Talebin varlığı,

- Malın pazardaki durumu, halihazırda var olan ve potansiyel müşteriler, 
- Benzer veya rakip mal ya da markaların varlığı ve pazardaki etkinlikleri,

- Tüketicileri bu mal ya da hizmeti satın almaya yönelten temel ve ikincil güdülerin neler olduğu,

- Mala ya da hizmete olan talebi etkileyen sosyal, hukuki, ekonomik ve doğal koşullar,

- Tüketicilerin mal ya da hizmete olan talebini etkileyen sosyal, hukuki, ekonomik ve doğal koşullar,

- Tüketicilerin mal ya da hizmete ya da üretici firmaya ilişkin düşünce, duygu ya da tutumları,

- Üretici firmanın finans ve işgücü kaynaklarının durumu,

- Reklam ortamları hakkında bilgi toplanır ve bu bilgiler değerlendirilir".

Yapılacak araştırmalar yukarıdaki temel soruların yanıtlarını ortaya koyacak sonuçlara sahip olmalıdır. Yapılan araştırmalar reklamveren firmanın pazardaki konumunu diğer rakiplere oranla nasıl edineceği, müşterilerinin neden kendisini tercih etmesi gerektiği konusunda ne tür fikir vereceği, bu tercihte rol oynayacak sosyal, hukuki, ekonomik ve doğal koşullarla ilgili ne tür bilgi vereceği, varolan ve muhtemel müşterilerinin işletmeye ilişkin tutumlarını sağlamlaştırmak ya da değiştirmek için neler yapılabileceği, bütün bunları içeren reklam mesajlarının hangi medyaların iletişim avantajlarından yararlanılarak izlerkitleye (audience) iletilebileceği gibi konularda bilgi sağlayacaktır. Bu sayede daha yaratıcı ve etkili reklam mesajlarının üretilmesi ve reklam kampanyalarının planlanması mümkün olabilecektir. Böylelikle reklam kampanyası için bir pazarlama ve reklam stratejisi saptanabilecek, ana mesaj ya da kampanyanın teması seçilebilecek, bunlar farklı iletişim araçlarına uygulanabilecek yaratıcı reklam örnekleriyle görsel ve sözel dile dökülecek, bunların yapım aşaması gerçekleştirilecek ve reklamlar için uygun medyalarda yer ve zaman satın alınacaktır. Sonrasında da kampanyanın değerlendirilerek yapılan araştırmalara dayalı olarak gerçekleştirilen reklam uygulamalarının başarısı ölçümlenecektir. Bu sürecin temel aşamalarını ise aşağıda olduğu gibi saptayabiliriz (Pride ve Ferrel, 2007: 417):

1. "Hedef kitlenin tanımlanması ve analiz edilmesi

2. Reklam amaçlarının belirlenmesi

3. Reklam platformunun yaratılması

4. Reklam bütçesinin belirlenmesi

5. Medya planının geliştirilmesi

6. Reklam mesajının yaratılması

7. Kampanyanın uygulanması

8. Reklam etkisinin değerlendirilmesi". 
Reklam kampanyasının tanımlanmasının, bir süreç olarak açıklanmasının ve araştırma ile ilişkisinin altının çizilmesinin ardından reklam kampanyalarının başarısı açısından reklam araştırmalarının taşıdığı önemi, uygulama boyutuyla ilişkisini ve reklam kampanyalarının yaratıcı boyutu ile ilişkisini incelemeye geçebiliriz.

\section{Reklam Kampanyası Öncesi Araştırmaların Aşamaları}

Reklam etkinliğinin ölçümlenmesinde reklam öncesi araştırmalar büyük önem taşımaktadır. $\mathrm{Bu}$ araştırmalar reklam mesajının oluşturulmasında büyük yarar sağlamalarının yanı sıra, reklam sonrası araştırmalarda elde edilen verilerin kıyaslamalı olarak değerlendirilmesinde de önem taşımaktadır. Reklam etkinliğinin ölçümlenmesini dört aşamaya ayıran Bootwala, Lawrence ve Mali, bu aşamaları şu şekilde açılamaktadırlar (Bootwala, Lawrence ve Mali, 2007: 3-4):

1. Geçmiş reklam tecrübesinin sürekli olarak analiz edilmesi, yeni reklamcılar ya da ürünler bulunması durumu haricinde oldukça yararlı bir ilk adımdır. Böyle bir analiz, reklam stratejisinin gözden geçirilmesinde ve geliştirilmesinde değerli bir temel sağlamaktadır.

2. Tüketici davranışı ve tercihleri üzerine araştırmalar reklam hedeflerinin ve stratejisinin geliştirilmesinde yardımcı olmaktadır. Böyle bir araştırma hedef kitledeki değişimleri gözlemlemekte yardımcı olacaktır.

3. Üçüncü alan reklamların piyasaya çıkmasından önce pre-testler ile ilgilidir. Pretestler reklamın ya da kampanyanın hedef pazar tarafından kabullenilmesi ihtimali konusunda bir gösterge sağladığı için oldukça önemlidir. Pre-test sonuçları reklamın ya da kampanyanın sınırlarını ortaya çıkaracak ve böylece reklam piyasaya çıkarılmadan önce değişiklikler yapılabilecektir. Bu ise reklamcıya zaman ve para tasarrufu sağlayacaktır.

4. Reklamın ya da reklam kampanyasının etkisinin ölçümlenmesinin son aşaması, post-test araştırmasıdır. Post-test araştırması reklamın amacını gerçekleştirme konusunda ne kadar başarılı olduğuna dair bilginin bulunması ile ilgilidir. Post-test aşaması, reklamın piyasaya çıktıktan sonra elde ettiği erişim ve etkinin test edilmesini içermektedir. Yapım öncesi araştırma ile yapım sonrası araştırma testi birbirini tamamlamaktadır.

Reklam kampanyası öncesi araştırmalar, burada da ifade edildiği gibi, daha etkili ve yaratıcı bir reklam mesajının doğru bir bütçelemeyle doğru hedef kitleye uygun bir biçimde iletilmesine yardımcı olduğu gibi, reklam kampanyası sonrasında elde edilen başarının ölçümlenmesi konusunda da yol gösterici olmaktadır. Burada saptanan alanlara uygun biçimde öncelikle pazar ve tüketici ile ilgili araştırma alanı üzerinde durulacak, daha sonra ise reklam kampanyası öncesi araştırma türleri ve yöntemleri ele alınacaktır.

\section{Reklam Kampanyası Süreci ve Araştırmaların Uygulama Boyutu}

Buraya kadar değinmiş olduğumuz gibi, reklam araştırmaları reklam kampanyasının her aşamasında hem reklamveren hem de reklam ajansı için önemli 
veriler sağlamaktadır. Reklam kampanyası oluşturulurken belirli bir süreç izlenmektedir. Öncelikle pazarlama stratejisi belirlenmekte, ardından kampanyanın ana konusu ve çekici noktası seçilmekte, konu farklı birçok medya kanalı için düzenlenmekte, sonrasında reklam prodüksiyonuna geçilmekte, seçilen medya kanallarından yer ve zaman satın alınmakta, son olarak da kampanyanın uygulanmasının ardından sonuçlar değerlendirilmeye alınmaktadır. $\mathrm{Bu}$ süreç sonucunda etkin bir reklam mesajı ile tüketiciye ulaşmak hedeflendiğinden, mesajın oluşturulması ve yaratıcılık konularında etkili olan pek çok öğeye ilişkin araştırma ve incelemeler yapılmaktadır. Kampanyanın başarısı için önemli bir paya sahip olan bu etkenleri genel çerçevede ve ayrı ayrı ele almak, kampanya ve reklama ilişkin süreçleri anlamak açısından yarar sağlayacaktır. Reklam kampanyasının planlama ve karar verme süreçleri aşağıda olduğu gibi gösterilebilir:

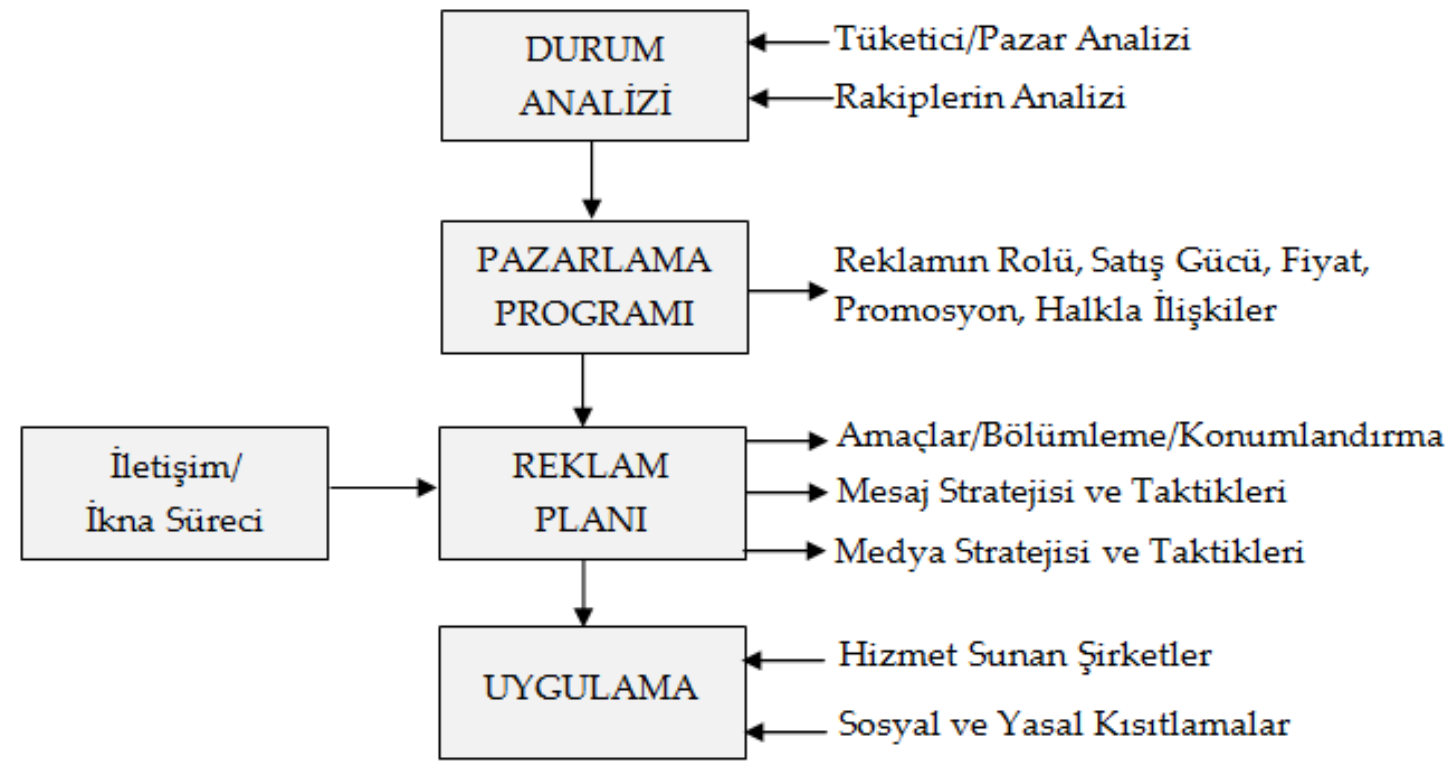

Şekil 1. Reklam Planlaması ve Karar Alma Süreci

Kaynak: Batra, Myers ve Aaker, 2009: 53

Reklam kampanyasının bütün aşamaları ise, araştırmalara dayalı olarak ve bu araştırmaların sonucunda elde edilen verilerin yaratıcı bir şekilde kullanılmasıyla gerçekleştirilmek durumundadır. Bu yüzden her aşamayı temel özellikleriyle değerlendirmekte yarar bulunmaktadır. Aşağıdaki bölümlerde reklam kampanyası öncesinde önem taşıyan araştırma konularının incelenmesi gerçekleştirilecektir.

\section{Durum Analizi: Pazarın Yapısı ve Rakiplerin Durumu}

Bir ürüne ilişkin kampanya hazırlamaya geçmeden önce belirli konular hakkında bilgi sahibi olmak, doğru bir kampanya stratejisinin oluşturulması için çok önemlidir. İşletme hem kendisinin hem de ürettiği mal veya hizmetin faaliyette bulunduğu pazar içindeki konumunu bilmek ve buna göre bir planlama yapmak durumundadır. "Reklam verenin, amaç ve bütçe belirlemede bağımsız olsa da, her yönden bağımsız davranamadığı, içinde bulunulan sosyal ve ekonomik çevrenin 
biçimlenmesinden etkilendiği, rakipler, yasal düzenlemeler, pazar ve tüketiciler gibi birbiriyle yakın etkileşim içinde olan tüm kurumlar açısından da tutarlı ve istikrarlı kararlar alması gerektiği açıktır" (Babacan, 2005: 48). Dolayısıyla pazarın yapısı hakkında bilgi edinmek, aynı alanda yarışacağı rakiplerin konumunu algılamak için de şarttır. İşletme, ürününün rakip işletmelerin ürünü karşısındaki avantaj ve dezavantajlarını yani güçlü ve zayıf yönlerini, yaşam evresini analiz etmeli, aynı pazarda yer kapma yarışı içinde öne geçebilmek için rakip ürünlerin de tüm özelliklerini bilmelidir. Çünkü bir ürün veya hizmeti sattıran temel unsur, onun tüketiciye sağladığı yarardır yani minimum fiyatla maksimum değeri sunmasıdır. Dolayısıyla hazırlanan kampanya hangi özel amaçlara sahip olursa olsun, her kampanyanın geri planında yatan temel amaç aslında pazarda pay kapmak ve markaya yönelik olumlu bir imaj yaratarak tüketici sadakatini oluşturmaktır.

Pazarın durumunu analiz ederken öncelikle rakiplerin pazar içindeki rekabet konumlarının değerlendirilmesi, pazar içinde rakiplerinizin güçlü ve zayıf oldukları yanların saptanmasını, kendi markanızın pazar içindeki güçlü ve zayıf yönlerini; kısaca söylemek gerekirse hem kendinizin hem de rakiplerinizin SWOT analizini de içine alan şekilde başlatılmalıdır. Aynı zamanda tüketicilerin rakip markalara karşı tutumları, rakiplerin reklam bütçeleri, vb. konular bu aşamada incelenme alanı içinde yer almalıdır. Bu şekilde şirketin uzun vadeli vizyon ve amaçlarına göre reklam kampanyasının sınırları belirlenmelidir.

\section{Kampanya Amacının Belirlenmesi}

Kampanya amacının belirlenmesi, kampanya süresince izlenecek yolun çizilebilmesi için gerekli bir ön koşuldur. Durum analizine yönelik araştırmalara dayalı olarak oluşturulan kampanya amacı, reklam kampanyası öncesindeki araştırmalar için olduğu kadar kampanya sonrası ölçümlemeler için de bir zemin sağlamaktadır. Kampanyanın amacı gözlemlenmek istenen etkinin uzun mu yoksa kısa sürede mi gerçekleşmesinin istenmesine, kampanyanın uygulanacağı alana yani yerel, ulusal ya da küresel ölçekte mi olacağına göre değişmektedir. "Şirketinizi / markanızı nereye götürmek istediğinizi bilmiyor olmak -gerçekçi olarak- en kötü haliyle bir yönetim hatasıdır. Mali başarısızlığa giden en kestirme yoldur. Gerçekçi hedefler belirlemek. Sürecin düzenli (ve sık sık) ölçümü... Bunlar harika markaların (ve kariyerlerin) oluşturulmasında mutlaka atılması gereken ilk adımlardır" (Lance ve Woll, 2006: 85). İşletme, piyasaya sürdüğü ürüne yönelik bir kampanya çalışmasına girişmeden önce reklam kampanyasının amacına ilişkin kararlar alırken, ilk olarak ürün ile ilgili olarak hangi kitleye sesleneceğine, bu kitleye ne söylemek istediğine, reklam ile başarılmak istenen duruma ve amaçlarını gerçekleştirmek için ayırabileceği bütçenin miktarına dikkat etmelidir.

Bu karar sürecinde işletmenin pazar içindeki konumu ve ihtiyaçları da etkili olmaktadır. Bu hedefler genel olarak hedeflenen satış miktarı ve kâr payı, pazarda edinilmek istenen konum, tüketicide uyandırılan imaj gibi konular üzerinde yoğunlaşmaktadır. Bu konular etrafında reklamın amaçlarının ifade ettiği noktalar şu şekilde saptanabilmektedir: yönetim düzeyinde konsensüs, bütçeleme için amaçlar 
oluşturma, mesaj ve medya stratejisi, hangi sonuçların ölçümlenebileceğine karşı standartlar sağlama. Burada çeşitli amaçlar reklam ajansına yol göstermektedir: Kim (hedef kitle), Ne (amaçlar ve vurgu), Nerede, Ne zaman ve Ne kadar sıklıkla? (Tyagi ve Kumar, 2004: 27). Kampanyanın amacının belirlenmesinin ardından reklam mesajının da bilgilendirme, ikna etme, ya da hatırlatma amaçlarından hangisine hizmet edeceğine de karar verilmesi gerekmektedir.

Reklamın amaçlarının kampanya oluşum sürecinde belirlenmesi, reklamın sonuçlarının ölçülebilir olmasına olanak tanımaktadır. Bu yolla neyin ölçümleneceğine dair fikir edinilmektedir. Başlangıçta belirlenen amaçlara ulaşılıp ulaşılmadığı yapılan araştırmalar sonucunda test edilebilmektedir. Ayrıca belirlenen amaç, hem kampanya için yürütülecek olan yaratıcı çalışmalar hem de mesaj ve medya stratejileri için önemli bir veri oluşturmaktadır.

\section{Amaca Uygun Hedef Kitlenin Belirlenmesi ve Tüketici Davranışının İncelenmesi}

Pazarlama amacı hakkında önemli noktaların belirlenmesinin ardından, pazar bölümlemesine geçildiğinde tüketici özelliklerinin araştırılmasında farklı kriterler göz önüne alınabilmektedir. "Tüketici davranışı karmaşık, dinamik, çok boyutlu bir süreçtir ve bütün pazarlama kararları tüketici davranışı hakkındaki varsayımlara dayalıdır" (Khan, 2007: 3). Bu nedenle gerek pazarlama gerekse reklam araştırmalarında tüketiciye yönelik her türlü bilginin edinilmesi doğru bir planlama yapılması açısından tartışılmaz bir önem taşımaktadır. Tüketici araştırmasının bu kadar büyük önem taşımasının nedeni, reklamın hedefine ulaşmasına yardımcı olmasıdır. Çünkü "bir reklam hedefi, tanımlanmış bir hedef kitlede, belirli bir düzeyde ve belirli bir sürede yerine getirilecek somut bir iletişim görevidir" (Dutka, 2002: 4). Hedef kitlenin belirlenmesi ve tüketici davranışının analiz edilmesi kapsamlı araştırmaları gerektirmektedir. Çünkü günümüzün post-fordist ve postmodern nitelikli pazar ortamında, tüketici davranışları birçok etkeni içine alan şekilde karmaşıklaşmıştır. Günümüz tüketicisi kültürel etkenleri göz önüne almakta, çevreci eğilimleri tüketim davranışına yansıtmakta, etnik, dinsel, toplumsal cinsiyete ilişkin duyarlılıklara özen göstermekte, belirleyici bir öğe olarak "yaşam tarzını" gözetmekte ve demografik açıdan çeşitlilik gösteren bir yapı sunabilmektedir.

$\mathrm{Bu}$ nedenle tüketici davranışını anlamlandırma aşamasında araştırmacılara yardımcı olmak için tüketici davranışı üzerinde etkili olan öğeler gruplara ayrılmakta ve her bir gruba yönelik detaylı analizler ile reklam kampanyasına yön verecek veriler elde edilmektedir. Hedef kitlenin özelliklerinin belirlenmesinde yönlendirici olabilen etkenler farklı şekillerde sınıflandırılabilmektedir. Bu tür bir sınıflamada etkenler üç gruba ayrılmaktadır: Demografik, psikografik ve sosyografik etkenler. Başka bir gruplama ise tüketici davranışı üzerinde belirleyici olabilecek etkenleri dışsal etkiler, içsel süreçler ve karar sonrası süreçler olmak üzere üç gruba ayırarak bir model sunmaktadir: 


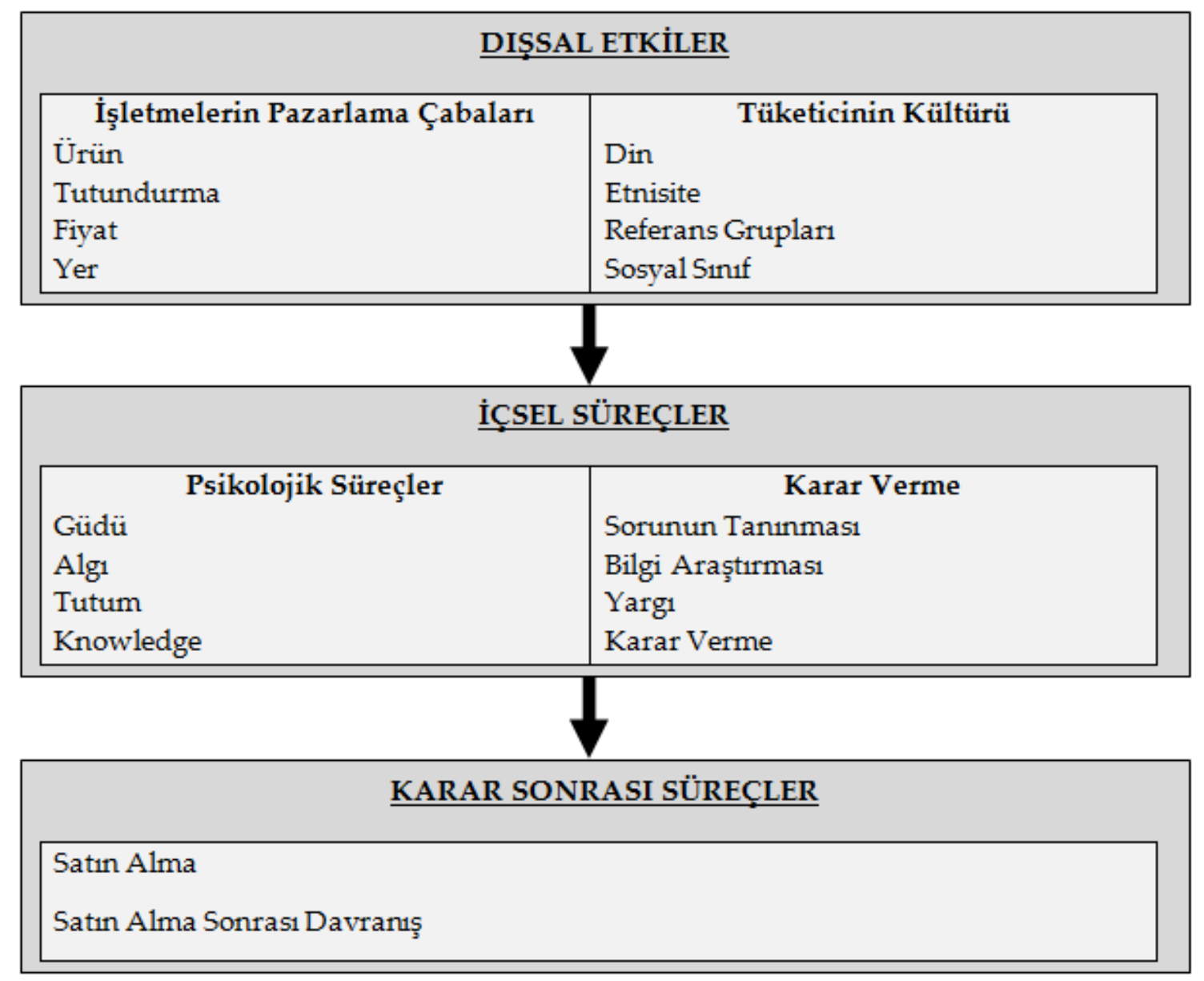

Şekil 2.Tüketici Davranışı Modeli

Kaynak: Noel, 2009: 14

Reklam etkinliğinin başarısının öngörülebilmesi için tüketici davranışını anlamlandırmaya yönelik belirli araştırmalar yapılmaktadır. Bu araştırmalar farklı yöntemler ile gerçekleştirilmektedir. Bu metodolojik yöntemleri iki grup altında toplamak mümkündür: Nitel araştırmalar ve nicel araştırmalar.

Nitel araştırmalar genellikle kampanya stratejilerinin belirlendiği sürecin ilk aşamalarında yapılmaktadır. Bu araştırmalar kapsamında araştırmacı ile hedef kitle arasında etkileşimi arttıran ve çoğunlukla açık uçlu olarak yapılandırılmış sorular ile yapılan görüşmeler ve fokus gruplar önemli yere sahiptir. Nitel araştırmalar, satın alma eylemine yönelik tüketicinin motivasyonlarını araştırmacının anlamasına olanak sağlamaktadır. Nitel araştırmanın dezavantajı, görüşmelerin ve fokus grupların küçük ölçekli tüketici grupları ile yapılmasıdır. Nitekim daha sonrasında daha geniş skaladaki tüketici kesimlerinin de dahil edilerek nitel araştırmanın sonuçlarının yeniden sınanması durumu söz konusu olabilmektedir. Nitel araştırmalar genellikle yeni fikirler edinme ya da tanıtım kampanyaları sürecinde başvurulan bir araştırma türü olarak işlev görmektedir. Bir diğer yöntem olan nicel araştırma yönteminde de yine tüketiciye yönelik bilgiler toplanmaktadır. Bu yöntem genellikle pazar karmasında yer alan farklı bileşenlerdeki değişimlerin etkilerini anlama amacıyla 
kullanılmaktadır. Dolayısıyla bu yöntem, tüketici davranışının öngörülmesine olanak sağlamaktadır. Nitel araştırmayla kıyaslandığında nicel araştırmada yapılandırılmış daha fazla sorunun sorulduğu ve araştırmacı ile hedef kitle arasında daha az etkileşimin olduğu dikkat çekmektedir. Nicel araştırma kapsamında deney, anket ve gözlem teknikleri kullanılmaktadır. Nicel araştırmanın sonuçları tanımlayıcı olmakla birlikte tüketici gruplarının nasıl davranacağını öngörme konusunda kullanılma imkanı sunmamaktadır (Noel, 2009: 24).

Tüketici davranışını anlamlandırma noktasında cinsiyet, yaş, medeni durum, meslek vb. gibi demografik faktörler ile aile, toplumsal statü ve roller, kültür vb. gibi sosyo-kültürel faktörler önemli etkenler olarak değerlendirilmektedir. Bununla birlikte daha karmaşık bir yapıya sahip olması nedeniyle güdüler, öğrenme, kişilik, algılama ve tutumlar gibi psikolojik faktörlerin etkisini ortaya koymak üzere daha fazla sayıda araştırmaların yapıldı̆̆ 1 dikkat çekmektedir.

Temelinde gereksinimlerin yer aldığ1 "güdü"lere yönelik olarak gerçekleştirilen araştırmalar, dişsal faktörlerin etkisini ve baskısını yok ederek, bu etkenlerden bağımsız bir şekilde bireyin kendi bireysel düşüncelerini yansıtmasını sağlamayı amaçlamaktadır. Bu yolla güdülerin hangi koşullar altında ve ne şekilde bireyi satın alma davranışına yönlendirdiği ortaya konmaya çalışılmaktadır. Güdü araştırmalarında iki yöntem kullanılmaktadır: Niteleyici yöntem ve projektif yöntem.

Niteleyici yöntemde yukarıda da belirtildiği gibi görüşme tekniği ön plana çıkmaktadır. Algıların, tutumların ve güdülerin etkisinin araştırıldığı bir çalışmada formel ya da yapılandırılmış görüşmeler çok uygun değildir. Bunun yerine daha esnek yapıya sahip olan ve konuşma süresince yeni soruların ortaya çıtı̆̆ yapılandırılmamış görüşmeler tercih edilmektedir. Bu nedenle niteleyici yöntem kapsamında açık uçlu soruların yer aldığı derinlemesine görüşme ya da fokus grup görüşmesi kullanılmaktadır. Fakat bu teknikte; sistematik bir yapının olmaması, görüşmeyi yapan araştırmacının etkisinin yüksek düzeyde olması, sonuçların görüşme yapılan birey temelinde geçerliliğinin olması, bir başka deyişle farklı bireylerle yapılacak görüşmelerden farklı sonuçların çıkabilecek olması, dolayısıyla daha subjektif verilerin elde edilmesi ve verilerin ölçümlenmeye uygun olmaması gibi sorunlar bulunmaktadır. Bu nedenle niteleyici yönteme kıyasla projektif yöntemin daha güvenilir olarak görülmesi sonucu ortaya çıkmaktadır. Projektif yöntemde ise pek çok farklı teknik uygulanabilmektedir. Bu yöntemde bireyler çözümlemek, açılamak ya da tamamlamak zorunda oldukları belirsiz bir durum ile kasten karşı karşıya bırakılmaktadır. Bu belirsiz durum kimi zaman bir kelime, kimi zaman eksik bırakılmış bir cümle, kimi zaman da bir resim olabilmektedir. Bu yöntem kapsamında kullanılan teknikleri "kelime çağrışım testi", "cümle tamamlama testi", "TAT testi (Thematic Apperception Test)", "hikaye tamamlama testi”, "boş balonlar" vb. şeklinde sıralamak mümkündür. Testlerdeki yapılandırılmamış ve muğlak yapı, içsel dürtülerin ortaya çıkarılmasında etkili olmaktadır. Bu yöntem bireyin kişilik yapısı, duygusal ihtiyaçları, değerleri, çelişkileri vb. hakkında tamamlayıcı bir resmi ortaya çıkarmayı amaçlamaktadır. Bu nedenle özelikle pazarlama araştırmaları kapsamında artan 
oranlarda tercih edilmektedir. Bununla birlikte yorumlama sürecindeki öznel yapısı yani nesnellikten uzak olması nedeniyle eleştirilmektedir (Beri, 2008: 209-214).

Güdülerin yanı sıra deneyimleme süreçleri sonucunda edinilen bilgileri vurgulayan 'öğrenme' aracılığıyla edinilen deneyimler de bireyin davranışlarının dayandığı bir diğer psikolojik faktördür. Öğrenme düzeyini tespit etmek için pazarlamacılar ve reklamcılar tarafından belirli yöntemler kullanılmaktadır. "Yeniden çağırma yöntemi" reklamcılar tarafından sıklıkla uygulanmaktadır. Bu yolla bireyin reklamı ne ölçüde hatırladığı ortaya konmaktadır. "Tanıtma yöntemi"nde potansiyel tüketiciye benzer ürünler veya paketler gösterilerek ondan bunları ayırt etmesi istenmektedir. "Yeniden öğrenme yöntemi"nde ise bireyin öğrenme sürecinde yaptı̆̆ hatalar gözlemlenerek onun yeniden öğrenmesi istenmektedir. Özellikle slogan seçiminde bu yöntemden sıklıkla faydalanılmakta, hangi sloganların akılda kalıcılığının yüksek olduğu bulunarak reklam mesajında o sloganın kullanılması tercih edilmektedir (Kavas, Katrinli ve Özmen, 1995: 108).

Bunların yanı sıra, daha önce de değinildiği gibi, "kişilik" de bireyin davranışlarını etkileyen önemli bir faktördür. Her bireyin kendine ait bir kişiliği vardır. Kişiye has bu karakteristik özellik her bireyi, dolayısıyla tüketiciyi biricik kılmaktadır. Kişiliğin oluşumuna katkıda bulunan etkenlerin belirlenmesi de reklamcılar açısından mesajın oluşturulmasında ve kullanılacak yaratıcı öğelerin seçiminde etkili olmaktadır. $\mathrm{Bu}$ nedenle kişiliğin belirlenmesine yönelik araştırmaların yapılması, etkili bir mesaj stratejisi sağlayacaktır. Özellikle Freud'un psikoanalitik kuramı, kişiliğin oluşum evrelerinin hepsine ait özelliklerin ortaya konmasını mümkün kılmaktadır. Freud'un güdülenmenin bilinçsiz olduğunu belirtmesinin aksine sosyo-psikolojik kuramin öncülerinden olan Carl Jung ve Alfred Adler, güdülenme sürecinin bilinçli olduğunu söylemektedirler. Adler kişilik oluşumunda temel güdünün güçlü olma isteği olduğunu belirtmektedir. Jung ise kişilik yapısını içe dönük ve dışa dönük olarak ayrımlamaktadır. Erich Fromm da bireylerin yalnızlık korkuları üzerine vurgu yaparak sevgi, güvenlik, endişe ve korku hislerinin kişiliği belirlediğini ifade etmektedir. Treyt (özellik) kuramı ise kişinin sahip olduğu özellikler tarafından kişiliğin belirlendiğine ve temel özelliklerin bilinmesi sonucunda kişiliğin öğrenilebileceğine vurgu yapmaktadır. Hangi kuramdan yola çıkılırsa çıkılsın kişiliğin belirlenmesinde uygulanan teknikleri üç farklı başlık altında toplamak mümkündür: Özellikle yüzyüze konuşma temeline dayanan "görüşme teknikleri", bireyin önceden hazırlanan testlere verdiği cevaplar sonucunda duygu ve düşüncelerini yansıtmasını sağlayan "projektif testler" ve bireyin kendini rapor ettiği bir yöntem olan "envanterler" (Odabaşı ve Barış, 2002: 192-203). Tüm bu kuramcıların sunduğu bilgiler 1şığında oluşturulan yaratıcı mesaj, gerek bilinçaltına seslenen "örtük" gerek ise "açık" göndermeler aracıllı̆ıyla, bireylerin eylemlerinin istenilen şekilde gerçekleşmesini sağlayabilecektir.

Bir diğer psikolojik faktör olan "algılama", her insanda farklı şekilde gerçekleşebilmektedir. Bunun nedeni, algının kişiden kişiye değişiklik gösteren güdülerden, tutum ve inançlardan, gereksinimlerden, kişilik özelliklerinden, grup ilişkilerinden vb. etkilenmesidir. Algılama konusunda özellikle "bilinçaltı uygulamalar" reklamcılar açısından oldukça sık kullanılmakta ve başarıya 
ulaşmaktadır. Algılamaya ilişkin süreçler ve algıyı belirleyen etkenler hakkında araştırma yapan bir reklamcı, mesajını, tüketiciyi çok daha fazla etkileyecek şekilde oluşturabilmektedir. Bu nedenle pazarlamacılar ve reklamcılar, "reklamın algılanması, ürün imajı, fiyata yönelik algılar, malın üretildiği yere yönelik algılar ve kurum imajı" (Odabaşı ve Barış, 2002: 147-148) gibi konuları ön planda tutarak araştırmaktadırlar. Reklamcılar özellikle medya ve mesaj araştırmalarında algının önemini göz ardı etmemektedirler. Çünkü tüketici ancak mesajın kendi çıkarlarına hizmet edeceğine karar verirse satın alma eylemine geçmektedir. Bu nedenle reklam hazırlanırken unutulmaması gereken nokta, diğerlerinden farklı ve üstün olarak, tüketicinin seçici algısına yönelik olarak üretilen mesajın dikkat çekeceğine ilişkin detaydır.

"Tutumlar" da yine reklamcilar tarafından inceleme alanına dâhil edilen konular arasında yer almaktadır. Tutumlar üzerinde, reklamcılar iki farklı strateji ile etkide bulunmayı amaçlamaktadırlar. "Adaptasyon stratejisi; hedef kitlenin istek, ihtiyaç ve beklentilerinin belirlenerek, ürün ve markalara ilişkin tutumların geliştirilmesi ve/veya yeni bir ürün ve markaya yönelik olarak mevcut tutumlar doğrultusunda yeni bir tutum yaratılması[dır]. Değişim stratejisi [ise] tüketicilerin istek, ihtiyaç ve beklentilerini çeşitlendirmek suretiyle X markasından Y markasına yönelmesinin sağlanması[dır]" (Fırlar, 2003: 73). Tutumu yaratmak, şiddetini arttırmak ya da değiştirmek olarak ifade edilen üç farklı etkinin yaratılabilmesi için tüketicinin tutumlarına ilişkin bilgilerin edinilmesi gerekmektedir. $\mathrm{Bu}$ nedenle reklam mesajlarında üründen önce ürünün yararı üzerine vurgu yapmak, tüketicinin dikkatini çekmek için önemli bir yöntem olarak kullanılmaktadır. Çünkü tüketici için önemli olan ürünün kendine sunacağı çözümdür.

Tutumların ortaya çıkarılıp hem pazarlama hem de reklam stratejilerinde kullanılabilmesi amacıyla üç farklı yöntem uygulanmaktadır. Bunlardan ilki bireyin davranışlarına yönelik "gözlem" yöntemi, ikincisi fokus gruplar, mülakatlar ve psikolojik testlerle tutumların ölçümlenmeye çalışıldığ1 "nicel araştırmalar" ve sonuncusu ise bireyin hisleri ve düşüncelerinin ölçümlenmeye çalışıldığı "anket yöntemi" dir (Odabaşı ve Barış, 2002: 169-170). Reklamlarda tüketicinin istenen tutumu sergilemesi için genellikle mizah, korku ve cinsellik duygularına vurgu yapılmaktadır. Genel olarak tutum üzerine yapılan araştırmalar, tüketicilerin özellikle markaya yönelik düşüncelerini ölçümlemede ve reklamlar aracılığıyla bu düşünceleri etkileyebilmek için reklam mesajını oluşturmada etkin olarak kullanılmaktadır. Yapılan araştırmalar sonucunda tutumların bilinmesi hem pazarlamacılar hem de reklamcılar için önemli veriler sağlamaktadır. Öğrenilen olumsuz tutumlar ikna edici ve bilgilendirici işlev gören reklamlar aracılı̆̆ıyla değiştirilmeye ve olumluya çevrilmeye çalışılmaktadır.

Özetle, kampanya öncesi reklam araştırmaları sürecinde önemli bir yer kaplayan ve tüketiciye yönelik olarak gerçekleştirilen araştırmalar, tüketici hakkında bilgilerin toplanmasına ve ardından analiz edilmesine olanak tanımaktadır. Bu yolla hedef kitlenin davranışları, davranışın altında yatan nedenler anlaşılarak çözümlenebilmekte, bu ise kampanyanın başarıya ulaşmasında temel teşkil etmektedir. Tüketici davranışını araştırmanın esas nedenlerinden birisi karlılığı arttırmaktır. 
Çünkü ancak tüketicinin kim olduğunun ve satın alma eyleminin neden, nasıl, ne şekilde ve ne sıklıkla gerçekleştiğinin anlaşılması durumunda pazarlamanın temel amacı olan satışa ulaşılacaktır. Naik ve Reddy'nin de belirttiği gibi, tüketici davranışında etkili olan ekonomik, psikolojik ve sosyolojik etkenlerin incelenmesi, pazarlamacıya, tüketicinin yeni ürünlere, fiyat değişikliklerine ve tanitım kampanyalarına nasıl tepki vereceğini öngörme fırsatını sunmaktadır. (Naik ve Reddy, 1999: 2). Dolayısıyla tüketici davranışı hakkında bilgi sahibi olmak reklam stratejileri de dahil olmak üzere pazara yönelik tüm stratejilerin belirlenmesi sürecinde yönlendirici olacaktır.

\section{Kampanya Stratejisinin, Yaratıcı Stratejinin, Medya Stratejinin ve Bütçenin Belirlenmesinin Araştırma Boyutu}

Reklam kampanyasının amacinın ve hedef kitlesinin belirlenmesinin ardından sıra, kampanyada ne tür bir stratejinin izleneceği konusuna gelmektedir. Strateji, kampanya ile tüketicilere neyin, nasıl söylenileceğine karar vermeyi sağlamaktadır. “İşletmeler reklam kararlarını işletme stratejileri ve pazarlama politikalarından bağımsız olarak alamazlar. İşletmenin yönetim anlayışına bağlı olarak belirlenen işletme misyonu işletmenin ürettiği mal veya hizmet türünün konumlandırılmasında da önemli rol oynar" (Babacan, 2005: 48). Bu nedenle strateji, reklam kampanyasının hemen her aşamasındaki temel kararların belirlenmesinde yol gösterici olacaktır. "Pazarlama iletişimi planından yola çıkan şirket ve reklam ajansı, reklam mesajının işlemesini sağlayacak bir konumlandırma ve yaratıcı strateji geliştirebilir ve nihayetinde mesajı iletebileceği bir medya stratejisi geliştirebilir" (Percy, RosenbaumElliot, 2012: 66). Kampanyanın stratejisi somut bir çıkış noktası sağlayarak, reklamcıların daha doğru temeller üzerine kurulu yaratıcı mesajlar üretmesine de olanak tanıyacaktır. Bu nedenle, gerekli her türlü bilgininin doğru saptanmış strateji doğrultusunda tüketiciye aktarılmasına özen gösterilmelidir. Bunun için de reklam öncesi araştırmalara dayalı bir şekilde, rakipler ve onların ürünleri hakkında yeterli bilgiye sahip olunmalı, dürüst şekilde ürün kıyaslaması yapılarak ürünün pazardaki benzerlerinden fazla ve eksik yönleri açıkça ortaya konmalı, kampanya stratejisi de bu veriler doğrultusunda hazırlanmalıdır.

Bunun için de öncelikli olarak pazara ve hedef kitleye yönelik araştırmanın yapılması ve elde edilen bulguların yaratıcı çalışmalar ile harmanlanması gerekmektedir. "Reklam ve iletişim stratejisi, geleneksel olarak tüketicileri gözlemleyip çözümlemekle olur. Tüketicinin ihtiyaçları, davranışları, satın alma alışkanlıkları, kullanılabilir geliri, yaşam tarzı, istekleri vb... Bu gözlemlerin toplamı, iletişim stratejisini oluşturup mesajlarımızı tanımlayacağımız bir dizi parametre yaratır. Ayrıca bize ürünümüzün, tüketicinin yaşamı bağlamında nasıl ve nerede sunulacağı hakkında çok değerli ve motive edici bilgiler sunar" (Anholt, 2003:70). Buradan yola çıkarak etkili bir mesaj için onun tüketici tarafından algılanıp yorumlanması, alımlama sürecinin sonucunda hatırlanması ve mesaja katkı sağlayan yaratıcı uygulamaların beğenilmesi gerektiğini söyleyebiliriz. 
Reklam mesajını oluştururken gerçekleştirilen yaratıcı çalışmanın zorluğu, bireyin gün içinde çok sayıda mesaj bombardımanına tutulan tüketiciye ulaşabilmektir. Bu mesajlar arasında bireyin ilgisini çekenler ya ihtiyacına yönelik bilgiler veren ya da yaratıcı olarak düzenlenen mesajlardır. Bu bağlamda "bir reklam kampanyası bir marka hakkında akılcı bir tutarlılığa sahip ve bütünleştirilmiş bir mesaj1 ileten bir dizi koordine edilmiş reklamlardan oluşmaktadır. Tema çeşitli iddialardan oluşturulabilir ama özünde tek bir tema geliştirilmelidir. Başarılı reklam kampanyaları çoklu medyada tek bir reklam etrafında geliştirilebilir ya da benzer görünüme, duyguya ya da mesaja sahip olan farklı reklamlarla oluşturulabilirler"'(O'Guinn, Allen, Semenik, 2011: 14). Reklam mesajında kullanılacak tema belirlenirken, kampanyanın amacı ve belirlenen hedef kitleye ait özellikler de özellikle dikkate alınmalıdır.

Bu bağlamda başarılı bir reklam ancak yaratıcı bir slogan, metin ya da görsel imgeler yardımıyla gerçekleştirilmekte ve ancak bu yolla hedef kitlenin dikkati ürüne ve markaya çekilebilmektedir. Bu yüzden reklam mesajları piyasaya çıkarılmadan önce test edilmektedirler. The Association of National Advertisers'in (Ulusal Reklamcilar Derneği) reklam mesajlarının ölçümlenmesinde yol gösterici olan dört ölçütü, bu konudaki araştırmaların içeriği hakkında yol göstericidir. Reklam mesajının dikkat çekip çekmediğinin, inandırıcı olup olmadığının, insanları ürünü satın almaya yöneltip yöneltmediğinin ve insanların markaya ve markanın reklamına karşı tutumlarının ne olduğunun ölçümlenmesi gerektiğini söyleyen Applegate, bu ölçütleri şu şekilde aktarmaktadır (Applegate, 2005: 212):

1. “Tek bir seçim ölçütü kullanın. (Bir test içinde birden fazla ölçütü ölçümlemek zordur).

2. Araştırmaya katılanlarla görüşme yapıldığında, testin tasarımını araştırmayı yanitlayanların reklam ya da reklam filmi ile ilgili olarak kendileriyle görüşme yapıldığını bilmeyecekleri şekilde yapın.

3. Reklamı bireylere evlerinde gösterin, böylece seyretme sürecinin bir testin parçası olduğu konusunda bir düşünceye kapılmayacaklardır.

4. Birden çok gösterim durumu yaratın. (Bu durum reklamın etkileri konusunda daha gerçekçi bir tayinde bulunmanızı sağlayacaktır)."

Araştırma konusu olan bütün bu konular kampanya bütçesinin belirlenmesinde de etkiye sahiptir. İşletmenin pazar stratejisinin (tutundurma ve reklam, vb.) ve kampanyanın amacının da bütçenin belirlenmesinde etkisi yüksektir. Bütçe belirlenirken, amaca uygun bir şekilde en yüksek verimi almaya yetecek miktar üzerinde karar verilmesi gerekmektedir. Bunu yaparken işletmenin geçmiş deneyimlerinden yararlanılabileceği gibi pazardaki rakip şirketlerin bütçe planlamalarından da faydalanılabilmektedir.

Bir reklam bütçesi hazırlanırken dikkate alınması gereken iki konu ön plana çıkmaktadır: "Birincisi, toplam reklam giderlerinin optimum düzeyinin belirlenmesi; ikincisi, belirlenen tutarın reklam araçları arasında dağıtımıdır... Dağıtım demek, 
giderlerin, reklam ortamı ya da medya adı verilen yayın araçları arasında nasıl paylaştırılacağıdır. Sorun, reklam ortamlarının, hedeflenen etkinlik düzeyini sağlayacak optimum bileşimini oluşturmaktır. Örneğin, gazeteye verilen reklam ile televizyonda yayınlanacak reklam paylarının belirlenmesi gibi" (Yükselen, 2003: 314). Reklam bütçelerinin oluşturulmasında farklı yöntemler uygulanmaktadır. Kampanyanın amacını ve stratejisini belirlemek, kampanyaya ilişkin olası giderlerin önceden tahmin edilmesine olanak sağlamaktadır. Bir reklam bütçesinde genel olarak kampanyayı hazırlayan ajansa ve reklamın yapımını üstlenen şirkete, eğer farklı tanıtım stratejileri yapılacaksa birlikte çalışılacak organizasyon şirketine ve son olarak da reklamların tüketiciye ulaştırılmasında araç olarak kullanılacak medyalara verilecek ücretlere ilişkin kalemler yer almaktadır.

Yaratıc1 strateji ile oluşturulan reklam mesajı için en uygun medyanın seçiminde temel amaç mesajın hedef kitleye ulaştırılmasıdır. Bu nedenle uygun bir medya stratejisinin belirlenmemesi, reklam mesajının etkileyici hazırlanmasına rağmen hedef kitleye ulaşılamaması riski yarattığından kampanyanın başarısız bir şekilde sonuçlanmasına neden olacaktır.

Bu nedenle medyaya ilişkin bir planlama süreci olarak tanımlayabileceğimiz medya stratejisi de süreçteki diğer boyutlar kadar önem taşımaktadır. “Mesaj stratejisi genellikle reklam metninin yaratılması ve test edilmesine ne kadar tahsisat ayrılacağ 1 ile ilgiliyken, medya stratejisi bir reklam kampanyasında ne kadar medya parasının harcanacağı ile ilgilidir" (Batra, Myers, Aaker, 2009: 65). Medya stratejisinin belirlenmesinde temel çıkış noktası, kampanya amacına uygun olarak hazırlanan reklam mesajlarının belirlenen hedef kitleye nasıl ve ne sıklıkta ulaştırılacağına karar vermektir. Medya stratejisi belirlenirken minimum bütçe ile maksimum verimin elde edilmesine ve hedef kitleye ulaşmayı sağlayacak en uygun reklam ortamının seçilmesine dikkat edilmelidir. Medya stratejisini belirlerken "bütçe olanakları, rekabet, reklama muhatap sayısı ve sıklığı, süreklilik, dağıtım kanalı etkisi, esneklik, reklam ortamı ile geliştirilen ilişkiler, reklam kabul standartları, hedef kitleye ulaşım maliyeti (yayılma oranı), mesajın etkinliği, potansiyel müşterilerin özellikleri" (Yükselen, 2003: 315) gibi faktörlerin dikkate alınması gerekmektedir. Dolayısıyla reklam ortamlarının seçiminde hem bütçe hem de hedef kitlenin yöneldiği medya araştırmalarına dayalı bilgiye ihtiyaç duyulmaktadır.

\section{Reklam Prototiplerinin Etkinliğinin Ölçümlenmesi}

Yukarıda değinmiş olduğumuz gibi, reklam araştırmaları kampanya öncesi, esnası ve sonrasında yapılan araştırmaları içermektedir. Bu araştırmaların temel amacı, planlanan reklamların amaçlarına uygun sonuçlar alıp alamayacağı ya da reklam bütçesinin doğru harcanıp harcanmayacağı konusunda ön veriler sağlamaktır. “Reklam etkinliğinin ölçümlenmesine yönelik araştırmaların başlıca amacı, etkili bir reklam içeriğinin belirlenmesine yardımcı olarak reklamın başarısının en üst düzeye çıkartılması ve reklam harcamalarında rasyonelliğin sağlanmasıdır. Ancak reklam etkinliğinin ölçümlenebilmesi için öncelikle reklamın amaçlarının yani reklamdan beklenen sonuçların açık ve kesin bir biçimde ve ölçüm yapmaya, değerlendirmeye 
olanak sağlayacak şekilde belirlenmesi gerekmektedir" (Kocabaş ve Elden, 1998: 9). Reklam etkinliğinin ölçümlenmesinde temel nokta, reklamın amacına mesaj vasıtasıyla ulaşılıp ulaşılamadığını ölçmektir. Reklam etkinliğinin ölçümlenmesine yönelik araştırmalar pre-test (ön test) ve post-test (son test) olarak ikiye ayrılmaktadır. Her iki araştırma türü de yine kendi içinde farklı yöntemleri barındırmaktadır. Dolayısıyla bir reklamın amacının belirlenmesinin ardından reklamın etkinliğinin ölçümlenmesi için amaca en uygun ölçümleme tekniği seçilmeli ve daha sonrasında elde edilen sonuçlar üzerinden reklamın etkinliğine dair yorumlarda bulunulmalıdır.

Bununla birlikte reklamların pre-test aracılığıyla başarısının tahmin edilmesi hem maliyetli olması hem de kesinliği konusunda kuşkuları barındırması gibi nedenlerden ötürü tartışma yaratabilmektedir. “Bazı araştırma şirketleri, bir reklamın başarısını pre-testle tahmin edebileceklerini ileri sürmektedirler. Ama akılda tutulmalıdır ki, bir pre-test gerçek yaşam değildir... Bu yüzden yapabileceğimiz en iyi şey, arzulanan etkiye sahip olma potansiyelini değerlendirmektir" (Baxter, 2005: 232). $\mathrm{Bu}$ değerlendirmenin de işaret ettiği gibi, reklam kampanyası öncesi yapılan ölçümlemeler bir anlamda reklamın hedef kitlesine yönelik olarak hazırlanmış reklam mesajlarının yaratıcılığının sınanması anlamına gelmektedir.

$\mathrm{Bu}$ nedenle reklamin yaratıcı boyutu ile ilgili olan reklamclar ile pre-test araştırmaları arasında bir gerilim ortaya çıkabilmektedir. Bu görüş doğrultusunda, reklamcıların pre-testlerin kendi yaratıcılıklarını olumsuz etkileyeceğinden ve yeni fikirlerin ortaya çıkarılmasını engelleyeceğinden çekindiğini belirten Becker, mevcut pre-test yöntemlerinin yaratıcı öğelerin etkilerini test etme konusundaki durumunu değerlendiren bir araştırma gerçekleştirmiştir. Becker'in araştırmasının sonuçları, incelenen dört kampanyadan üçünde olumlu sonuçlara ulaşıldığını saptayarak pretestlerin yararlı olduğu ve pre-testlerin yaratıcılı̆̆ı öldürmediği sonucunu ortaya koymuştur (Becker, 2004: 163).

Pre-test yönteminde reklamların taslak halleri hedef kitleyi temsil eden örneklem grubuna izletilmekte ve yapilan testler sonucunda edinilen veriler doğrultusunda reklama son şekli verilmektedir. Bu yolla hataların önüne geçilmeye çalışılmakta ve en uygun mesajın hazırlanmasına olanak sağlanmaktadır. Bu bağlamda yönteminin amaçları aşağıda olduğu gibi saptanabilir:

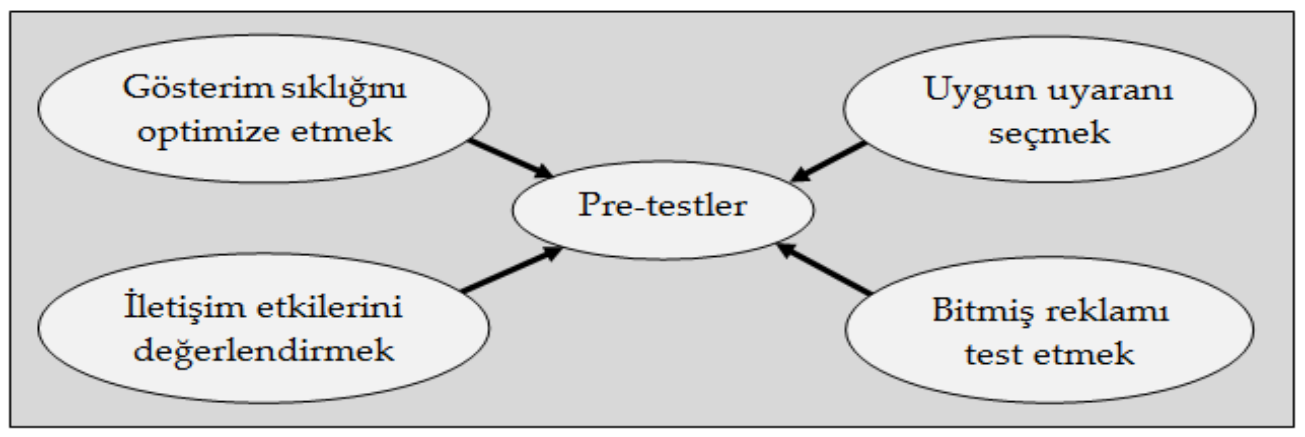

Şekil 3. Pre-Test Yönteminin Amaçları

Kaynak: Pelsmacker, Geuens ve Bergh, 2000: 224. 
Her araştırma yönteminde, hedef kitle olarak belirlenen tüketicilerin reklama ilişkin düşüncelerinin, tutumlarının ve ilgi düzeylerinin belirlenmesi amaçlanmaktadır. Pre-testler yoluyla da hedef kitleyi temsilen bir örneklem kümesi oluşturulmakta ve araştırma yöntemleri bu grup üzerinde uygulanmaktadır. Pre-testler kendi içinde birçok farklı yöntemi içermektedir. "Tüketiciye anket formu aracılığı ile sorular sorulabilir; laboratuar koşullarında bazı mesajları ne ölçüde izledikleri, ne kadarını hatırladıkları incelenebilir. Bu tür ölçmelerde en önemli sorun, hatırlamanın ne ölçüde reklamdan kaynaklandığını saptamaktır" (Yükselen, 2003: 318). Genel olarak bu şekilde aktarılabilecek olan pre-test araştırmaları sırasıyla tanıtmak reklam araştırmalarını ve etkisini ortaya koymak açısından yararlı olacaktır. Trehan ve Trehan'ın sinıflandırmasından (Trehan ve Trehan, 2007: 180-182) yararlanarak, kampanya öncesi pre-testing yöntemlerini şu şekilde sıralamak mümkündür:

1. Tüketici Jürisi Yöntemi: Bu yöntem içinde, reklamın etkisi, farklı coğrafi alanlardan, farklı geçmişe sahip olan ve farklı tüketici sınıflara ait seçme tüketicilerin oluşturduğu jüri üyeleri tarafından değerlendirilir.

2. Reklam Konsepti Testi: Bu yöntem reklam metni geliştirilirken kullanılır. Önerilen çeşitli ifadeler, başlıklar, görseller, renkler, vb. farklı coğrafyalardan gelen tüketicilere gösterilir. Tüketicilere göre bunlardan hangilerinin daha çekici olduğunu saptamak üzere farklı konseptlerin zayıf ve güçlü yönlerini ortaya koyma amaçlı bir soru formu hazırlanır.

3. Deneme Alanı Testi: Bu yöntem içinde, reklam tüm pazara yönelik olarak yayına çıkmadan önce, yaklaşık olarak benzer düzeyde ekonomik ve pazar koşullarına sahip olan ve "test kenti" ve "kontrol kenti" olarak seçilen iki kentteki durum üzerinden değerlendirilir. Test kentinde reklam gösterilirken, kontrol kentinde reklam gösterilmez ve iki kentteki satış artışı reklamın etkisini değerlendirmek üzere kıyaslanır.

4. Yayınlanacak Reklamın Testi: Bu yöntem içinde indirim kuponu verilen iki grup tüketiciden birisine reklam gösterilirken diğerine gösterilmez. Daha sonra indirim kuponlarıyla yapılan satışlar kıyaslanarak reklamın etkisi ölçümlenir.

5. Göz Hareketi Kamera Testi: Özellikle pahalı bir reklam türü olan açıhava reklamcılığında kullanılan bu yöntem içinde, reklamın üzerine yerleştirilen bir kamera aracılığıyla insanların göz hareketleri kaydedilir. Bu şekilde ilgi ve dikkat alanları saptanarak reklam mesajlarının bu alanlara yerleştirilecek şekilde tasarımı yapılır.

6. Doğrudan Posta Testi: Reklamlar özellikle posta yoluyla yapılacağında, bu test yöntemi kullanılarak muhtemel müşteriler arasından seçilen kimselere reklamlar postalanır. Reklamı yapılan ürünü ısmarlayan tüketicilerin sayısı aracılığıyla reklamın etkisi ölçümlenir. Bu yöntem ayrıca farklı reklam metinlerinden hangisinin daha etkili olduğunun ölçümlenmesi için de 
kullanılmaktadır. Geri dönüşü daha fazla olan reklam metninin en etkili olduğu kabul edilmektedir.

7. Evde Gösterim Testi: Bu yöntem içinde, bir projeksiyon cihazı yardımıyla reklam tüketicilere evlerinde gösterilir. Reklam hakkında farklı içeriklere sahip sorular aracılığıyla reklamın zayıf ve güçlü yönleri saptanır. Zayıf noktalar düzeltilerek reklam yayına hazırlanır.

8. Televizyon Yayını Testi: Bu yöntem içinde, test-reklamları belirli pazarlardaki televizyon yayınlarında gösterilir. Test pazardaki tüketicilerin tepkilerine göre düzeltilmiş olan reklamlar bütün pazar içinde yayınlanır.

9. Sinema Salonu Testi: $\mathrm{Bu}$ yöntem içinde, televizyon reklamları yayınlanmadan önce sinema salonuna davet edilen tüketicilere gösterilir. $\mathrm{Bu}$ seyircilerin reklami seyretmeden önce ve sonra verdikleri cevaplar değerlendirilerek reklamın etkisi ölçümlenir.

10.Laboratuvar Testleri: $\mathrm{Bu}$ yöntem içinde, bazı bilimsel yöntemlerle deneklerin reklama karşı tepkileri avuç içi terlemelerinin, gözbebeği hareketlerinin ölçülmesiyle ve gösterilen görüntülerin hızına verdikleri tepkiler aracılığıyla ölçümlenmekte; test sırasında kalp atışları ve kalp basınçları değerlendirilmektedir. Bu ölçümlemelerle reklamın etkisi değerlendirilmektedir.

Pre-test araştırmaların yapılması yoluyla reklam kampanyasının uygulamasına geçilmeden önce reklamın amacı ile etki yönünden olası sonuçlarının karşılaştırması yapılabilmekte ve bu sayede olası sorunların önceden belirlenip önüne geçilmesi söz konusu olabilmektedir. Bunun sonucunda daha baştan reklamın başarısı test edilmiş olmakta ve olumsuz sonuçların öngörülebilmesi nedeniyle belirli miktarda maliyet tasarrufu da sağlanmaktadır.

Sonuç olarak, reklam kampanyası öncesinde gerçekleştirilen pre-testlerde taslak prototiplerin kullanılması şu avantajları sağlamaktadır (Pierce, 2004, 162):

- Farklı reklam seçenekleri hazırlamanın yüksek maliyetli prodüksiyonundan kaçınmak,

- Pre-testlerde etkililikleri kanıtlanmış yani çok satış vadeden 'kaymak' reklamların üretilmesi ve bu yolla maliyet açısından verimliliğin arttırılması,

- Değişiklik yapılması ya da geliştirilmesi gereken strateji ve uygulamalar hakkında yönlendirici verileri sağlamak,

- Piyasaya yeni sürülen bir ürünün 'tutunabilirliğini', araştırmaların görsel-işitsel verileri aracılığıyla kanitlamak,

- Pre-testler sayesinde reklamın etkinliğine ilişkin bilgilerin edinilmesi yoluyla, yapılan her reklamı, 'prodüksiyon maliyetinin yüksekliği' nedeniyle haklı görme zorunluluğunu ortadan kaldırmak. 


\section{SONUÇ}

Günümüz reklamcılığında araştırma yaşamsal bir öneme sahiptir. Çünkü bir reklam kampanyasının birçok farklı değişkenden oluşması bu süreci karmaşıklaştırmaktadır. Bu karmaşık süreci mümkün olduğunca basite indirgemek için bu süreçte etkili olan her faktörün özellikleri ayrı ayrı ele alınmalı ve bunların etkililik derecesi hiçbir zaman göz ardı edilmemelidir. Kampanyanın hedef kitlelere ulaştırılması aşamasında devreye giren reklamın oluşum sürecinde de benzer faktörlerin etkisi gözlemlenmektedir. Bu noktada rasyonel kararlar alabilmek için, reklamın yayınlanmasından önceki süreci kapsayacak şekilde araştırmalar yapılmaktadır. Zaman aşımı, rakip firmaların tüketiciye eş zamanlı olarak ilettikleri mesajlar, pazarın yapısında ve ekonomik çevrelerde meydana gelen değişimler, değişken yapı arz eden maliyetler gibi birçok faktör reklam kampanyasının etkinliğinin önünde engel olarak yer almaktadır. Bu engellere takılmadan amaca ulaşıp başarıyı yakalamak ise reklam araştırmaları sonucunda edinilen verilere dayanarak rasyonel kararlar almayı ve bunları sorunsuz bir şekilde uygulamayı gerektirmektedir. Ayrıca kampanya öncesi reklam araştırmalarının kısıtlamalarını ve eksik yönlerini de göz ardı etmeden, bir kampanya için farklı yöntemleri aynı anda deneyerek verilerin doğruluğunun test edilmesi kampanyanın başarıya ulaşması açısından büyük öneme sahiptir.

\section{KAYNAKÇA}

Anholt, S. (2003). Global Markaların Yerel Çuvallamaları. (G. Canan, Çev.). İstanbul: MediaCat Kitapları.

Applegate, E. (2005). Strategic Copywriting: How to Create Effective Advertising. Lanham: Rowman and Publishers, Inc.

Babacan, M. (2005). Reklamcllk: Temel Kavramlar, Ankara: Detay Yayıncilık.

Batra, R., Myers, J.G., Aaker, D.A. (2009). Advertising Managemenet. New Delhi: Dorling Kindersley Pvt. Ltd..

Baxter, M. (2005). Consumer Research, The Practice of Advertising. (A. Mackay, Ed.). Burlington: Elsevier Butterworth-Heinemann.

Becker, J. (2004). Success in the Pretesting of Advertising Campaigns, Content and Media Factors in Advertising. (P. Neijens, C. Hess, B. van den Putte, ve E. Smith, Ed.). Amsterdam: Het Spinhuis Publishers.

Beri, G.C. (2008). Marketing Research. New Delhi: Tata McGraw-Hill Publishing Company.

Bootwala, S., Lawrence, M.D., Mali, S.R. (2007). Advertising Sales Promotion. B.B.A. Sem. IV, Pune: Nirali Prakashan.

Dutka, S. (2002). Dagmar: Ölçülür Reklam Sonuçları İçin Reklam Hedeflerini Tanımlamak. (H. Mesci, Çev.). İstanbul: Reklamcılık Vakfı Yayınları.

Fırlar, B.G. (2003). Reklam ve Biz, İzmir: Dokuz Eylül Yayınları.

Kavas, A.C., Katrinli, A., Özmen, Ö.T. (1995). Tüketici Davranışları. Eskişehir: Anadolu Üniversitesi Yayınları. 
Khan, M. (2007). Consumer Behaviour. New Delhi: New Age International Ltd Publishers.

Kocabaş, F., Elden, M. (1998). Reklam Etkinliğinin Ölçümlenmesinde Pre ve Post Testler, Düşünceler, 11 (11), İzmir: Ege Üniversitesi Basımevi.

Kocabaş, F., Elden, M. (2006). Reklamcilı: Kavramlar, Kararlar, Kurumlar, (9. Bask1) İstanbul, İletişim Yayınları.

Lance, S., Woll, J. (2006). Reklamcllığın Turuncu Kitabı: Fark Yaratan 52 Büyük Fikir. (İ. B. Kalınyazgan, Çev.). İstanbul: Kapital Medya Hizmetleri A.Ş.

Naik, C.N.K., Reddy, L. V. (1999). Consumer Behaviour. New Delhi: Discovery Publishing House.

Noel, H. (2009). Basics Marketing 01: Consumer Behaviour. Lausanne: AVA Publishing.

O'Quinn, T., Allen, C., Semenik, R. (2011). Advertising and Integrated Brand Promotion. Mason: Cengage Learning.

Odabaşı, Y. (1995). Pazarlama İletişimi. Eskişehir: Anadolu Üniversitesi İşletme Fakültesi Yayınları.

Odabaşı, Y., Barış, G. (2002). Tüketici Davranışı. İstanbul: Kapital Medya Hizmetleri A.Ş.

Pelsmacker, P.D., Geuens, M., Bergh, J. Van den. (2000). Marketing Communications Essex. England: Pearson Education Ltd.

Percy, L., Rosenbaum-Elliot, R. (2012). Strategic Advertising Management. Oxford: Oxford University Press.

Pierce, P. (2004). Araştırmada, Taslak Reklamlara Karşı Tamamlanmış Reklamlar, Reklam Nasıl İşe Yarar: Araştırmanın Rolü. (J. P. Jones, Der.). ( M. Dilber, ve D.Ü. Biçicioğlu, Çev.). İstanbul: Reklamcılık Vakfı Yayınları.

Pride, W.M., Ferrel, O.C. (2007). Pride-Ferrel Foundations of Marketing. Boston: Cengage Learning.

Theron, D. (2007). Promotion Decisions. Introduction to Marketing. (J. Strydom, Ed.). Cape Town: Juta and Co. Ltd.

Trehan, M., Trehan, R. (2007). Advertising and Sales Management. New Delhi: V.K. (India) Enterprises.

Tyagi, C.L., Kumar, A. (2004). Advertising Management. New Delhi: Atlantic Publishers and Distributers.

Yükselen, C. (2003). Pazarlama: Illkeler - Yönetim. Ankara: Detay Yayıncılık. 